\title{
Keracunan Pestisida dan Hipotiroidisme pada Wanita Usia Subur di Daerah Pertanian
}

\author{
Suhartono*, Dharminto**
}

\begin{abstract}
Abstrak
Wanita bermukim di daerah pertanian berisiko terpajan pestisida yang dapat berakibat hipotiroidisme yang pada kehamilan dapat menyebabkan gangguan tumbuh-kembang janin. Tujuan penelitian ini adalah mengetahui angka kejadian keracunan pestisida dan hipotiroidisme pada wanita usia subur di daerah pertanian. Penelitian ini menggunakan disain penelitian cross-sectional dan 26 WUS terpilih sebagai subjek secara acak. Semua subjek dilakukan pengukuran kadar TSH, IT4 dan enzim kolinesterase, sementara kadar T3, UEI, dan Pb darah diukur pada sub-sampel. Penderita dinyatakan keracunan pestisida apabila ditemukan kadar enzim kolinesterase $<3,9 \mu \mathrm{g} / \mathrm{L}$ dan dinyatakan hipotiroidisme apabila kadar TSH $>4,5 \mu$ lU/L. Penelitian ini menemukan rerata kadar kolinesterase adalah 7,26 $( \pm 1,28)$ dengan kisaran nilai 5,33-9,39 $\mu \mathrm{g} / \mathrm{L}$; rerata kadar TSH adalah 5,09 $( \pm 6,14)$, dengan kisaran nilai 0,47-31,73 $\mu$ IU/L; rerata kadar fT4 adalah 15,18 ( $\pm 2,09)$, dengan kisaran nilai 8,73-18,87 pmol/L; rerata kadar T3 adalah 1,75 ( $\pm 0,51)$, dengan kisaran nilai 1,24-2,95 pmol/L. Prevalensi keracunan pestisida pada WUS 0,0\% dan prevalensi hipotiroidisme $46,2 \%$.
\end{abstract}

Kata kunci : Pestisida, hipotiroidisme, wanita usia subur, daerah pertanian

\begin{abstract}
Women lived in agricultural areas are risk to suffer various disorders due to pesticides exposure such as hypothyroidism. Hypothyroidism causes growth and development disorders of fetus. The aim of the study is to find out the prevalence of pesticide poisoning and hypothyroidism in women of childbearing age in agricultural areas. Cross-sectional study was conducted and 26 women of childbearing age were selected randomly. TSH, fT4 and cholinesterase enzyme levels were measured in all subjects, while levels of T3, UEl and blood $\mathrm{Pb}$ were measured in the sub-sample. Pesticide poisoning is determined if the levels of enzymes cholinesterase $<3.9 \mu \mathrm{g} / \mathrm{L}$ and determined as hypothyroidism if the TSH $>4.5 \mu \mathrm{lU} / \mathrm{L}$. This study showed that mean of cholinesterase levels was 7.26 ( \pm 1.28), range of values $5.33-9.39 \mu \mathrm{g} / \mathrm{L}$; mean of TSH levels was $5.09( \pm 6.14)$, range of values $0.47-31.73 \mu \mathrm{IU} / \mathrm{L}$; mean of fT4 level was 15.18 ( \pm 2.09), range of values $8.73-18.87 \mathrm{pmol} / \mathrm{L}$; mean of T3 levels was $1.75( \pm 0.51)$, range of values $1.24-2.95 \mathrm{pmol} / \mathrm{L}$. The prevalence of pesticide poisoning in childbearing women was $0.0 \%$ and prevalence of hypothyroidism was $46.2 \%$.

Key words : Pesticide, hypothyroidism, women of childbearing age, agricultural area


Wanita usia subur (WUS) yang bertempat tinggal di daerah pertanian merupakan populasi yang berisiko menderita berbagai gangguan akibat pajanan pestisida. Hal ini berkaitan dengan peranan mereka secara langsung dalam kegiatan pertanian atau akibat pengelolaan pestisida yang tidak aman di lingkungan rumah. Beberapa penelitian menunjukkan bahwa pajanan pestisida berpengaruh negatif terhadap fungsi tiroid. Secara empiris terbukti bahwa pajanan pestisida golongan organoklorin dan organofosfat akan menekan produksi hormon T4 dan T3 serta meningkatkan hormon Thyroid Stimulating Hormone (TSH). ${ }^{1-3}$ Gangguan fungsional tersebut dikenal sebagai hipotiroidisme, suatu keadaan kelenjar tiroid tidak dapat memproduksi hormon yang cukup untuk memenuhi kebutuhan tubuh. ${ }^{4,5}$

Hipotiroidisme yang terjadi pada anak dapat mengakibatkan gangguan tumbuh kembang, seperti ukuran tubuh yang tidak sesuai umur (cebol) dan Intelligence Quotient (IQ) yang rendah (gangguan kecerdasan) bahkan sampai retardasi mental.6-8 Pada wanita hamil, hipotiroidisme menyebabkan gangguan pertumbuhan dan perkembangan janin yang dikandungnya. ${ }^{7,8}$ Penelitian epidemiologi akhir-akhir ini juga menyoroti tentang dampak jangka panjang gangguan fungsi tiroid sub-klinis di awal kehamilan, khususnya hipotiroidisme terhadap gangguan perkembangan psikomotor seorang anak. $^{9}$

Hipotiroidisme merupakan penyebab gondok yang utama. Rendahnya hormon tiroid akan meningkatkan produksi TSH, suatu hormon yang akan meningkatkan sintesis hormon tiroid dan merangsang pembesaran kelenjar tiroid. ${ }^{4}$ Penyebab tersering gondok, khususnya di daerah endemis, adalah kurangnya asupan yodium, yang merupakan bahan baku utama dalam sintesis hormon tiroid. Gondok endemis umumnya ditemukan di daerah dataran tinggi, karena kandungan yodium pada tanah, air, dan produk-produk pertanian di daerah tersebut sangat rendah, sehingga penyakit gondok sering disebut juga sebagai GAKY (Gangguan Akibat Kekurangan Yodium). 7,10

Beberapa informasi terakhir menyebutkan bahwa angka kejadian gondok di beberapa daerah dataran rendah ternyata juga tinggi, kandungan yodium dalam air, tanah dan produk-produk pertanian di daerah tersebut mestinya cukup memadai. ${ }^{11}$ Berkaitan dengan hal tersebut muncul beberapa teori, antara lain kemungkinan terpajan oleh kontaminan di lingkungan yang dapat menyebabkan gangguan fungsi tiroid, seperti logam berat $(\mathrm{Pb}$, $\mathrm{Hg}$ dan $\mathrm{Cd})$, polychlorinated biphenyl (PCB), dan pestisida. ${ }^{11-13}$

Kabupaten Brebes di Jawa Tengah adalah wilayah dengan tingkat pemakaian pestisida yang cukup tinggi, akibat lahan pertanian yang luas, khususnya bawang merah. Kecamatan Kersana merupakan salah satu wilayah di Kabupaten Brebes yang mengandalkan komoditas di bidang pertanian, seperti padi, bawang merah, jagung dan kacang hijau serta cabai dengan produktivitas tertinggi tanaman bawang merah yang mencapai 84,4 kwintal/hektar.

Pemeriksaan yang dilakukan Dinas Kesehatan Kabupaten Brebes tahun 2007 pada murid di tiga Sekolah Dasar (SD), di Kecamatan Kersana menunjukkan angka Total Goitre Rate (TGR) mencapai 43,7\%. Menurut kriteria WHO, angka TGR $\geq 30 \%$ tergolong tinggi (berat). ${ }^{14}$ Angka TGR yang tinggi pada murid SD di Kecamatan Kersana tersebut patut diduga akibat pajanan pestisida, sementara, angka TGR pada WUS belum tersedia. Padahal, dampak pajanan pestisida dan gangguan fungsi tiroid yang serius pada WUS, seperti abortus, gangguan tumbuh kembang janin dan gangguan psikomotor pada anak akibat ibu menderita disfungsi tiroid ketika hamil. Oleh sebab itu, perlu dilakukan penelitian tentang keracunan pestisida dan gangguan fungsi tiroid, khususnya hipotiroidisme, pada WUS di daerah pertanian.

Desa Limbangan, merupakan salah satu desa di Kecamatan Kersana, Kabupaten Brebes dengan tingkat pemakaian pestisida tertinggi. Berkaitan dengan hal tersebut, perlu dilakukan kajian awal tentang berapa besar kejadian keracunan pestisida dan disfungsi tiroid (hipotiroidisme) pada WUS di desa Limbangan, Kecamatan Kersana, Kabupaten Brebes. Pertanyaan penelitian yang diajukan pada penelitian ini adalah: "Berapa angka kejadian keracunan pestisida dan hipotiroidisme pada WUS di desa Limbangan, kecamatan Kersana, kabupaten Brebes?”.

\section{Metode}

Penelitian ini menggunakan desain penelitian Crosssectional dengan populasi target adalah semua WUS yang bertempat tinggal di daerah pertanian, sementara populasi terjangkau adalah WUS yang bertempat tinggal di Desa Limbangan, Kecamatan Kersana, Kabupaten Brebes. Desa tersebut dipilih secara purposif, dengan pertimbangan tingkat pemakaian pestisida yang terbesar di daerah tersebut. Subjek penelitian adalah sebanyak 26 WUS yang bertempat tinggal di desa Limbangan. Jumlah subjek ditentukan berdasarkan judgement peneliti, dengan memperhitungkan ketersediaan biaya. Kriteria inklusi subjek adalah umur 17 - 40 tahun, tidak sedang hamil, dan tidak sedang menderita sakit berat.

Variabel yang diukur untuk seluruh subjek meliputi karakteristik subjek (umur, status pernikahan dan keterlibatan WUS dalam kegiatan pertanian) dan kadar TSH. Selain itu, pada kelompok sub-sampel, yang dipilih secara acak, juga akan dilakukan pemeriksaan tingkat asupan yodium, dengan mengukur ekskresi yodium dalam 
urin $($ Urinary Excretion of Iodine = UEI); kadar fT4, T3 dan kadar enzim Cholinesterase. Variabel karakteristik subjek diukur dengan menggunakan kuesioner terstruktur; kadar TSH diukur dengan metode Elecsys immunoassay systems (satuan $\mu \mathrm{IU} / \mathrm{L}$ ); kadar fT4 diukur dengan metode Electrochemiluminescence immunoassay "ECLIA" (satuan pmol/L); kadar enzim Cholinesterase diukur dengan reagen $S$-buthyrylthiocholine iodide merk Integra Roche ( $\mu \mathrm{kat} / \mathrm{L})$; dan kadar UEI diukur dengan metode Ceric Ammonium Sulfat ( $\mu \mathrm{g} / \mathrm{dL}$ ).

Petugas pengumpul data adalah mahasiswa Program Studi Magister Kesehatan Lingkungan Program Pascasarjana Universitas Diponegoro yang telah mendapatkan pelatihan sebelumnya. Pengambilan sampel darah dan pemeriksaan parameter fungsi tiroid (TSH, fT4, dan T3) dan kadar enzim Cholinesterase dilakukan oleh Laboratorium Klinik Cito, sementara pemeriksaan kadar UEI dan kandungan $\mathrm{Pb}$ dalam darah dilakukan di Laboratorium GAKY Fakultas Kedokteran Undip. Kategori/pengelompokan hasil pemeriksaan kadar TSH adalah: normal/eutiroid $(0,15-4,5$ $\mu \mathrm{IU} / \mathrm{L})$ dan hipotiroidisme (> 4,5 $\mu \mathrm{IU} / \mathrm{L})$. Untuk fT4, batasan hipotirodisme adalah $<7 \mathrm{pmol} / \mathrm{L} .{ }^{15}$ Bila didapatkan kadar TSH > 4,5 $\mu \mathrm{IU} / \mathrm{L}$ dan kadar fT4 normal, dikelompokkan sebagai hipotiroidisme sub-klinik. ${ }^{16}$ Asupan yodium dianggap normal, bila nilai median $\geq$ $150 \mu \mathrm{g} / \mathrm{d} .{ }^{14}$

Sehari sebelum pengambilan data, kepada seluruh calon subjek dibagikan lembar penjelasan yang berisi tentang identitas peneliti, tujuan dan manfaat penelitian, risiko yang mungkin timbul akibat penelitian ini dan bagaimana upaya mengatasinya. Pada hari pelaksanaan pengambilan data, penjelasan tersebut diulang kembali oleh peneliti dan setelah subjek memahami penjelasan tersebut, subjek diminta menandatangani form informed consent. Data yang terkumpul diolah dengan menggunakan software SPSS, dan disajikan nilai rerata, simpang baku (SB), nilai minimum, maksimum dan median untuk variabel berskala rasio. Variabel berskala nominal atau ordinal disajikan dalam tabel distribusi frekuensi. Uji Chi-square digunakan untuk menganalisis perbedaan proporsi kejadian hipotiroidisme antara kelompok WUS yang terlibat dan yang tidak terlibat dalam kegiatan pertanian.

\section{Hasil}

Pengambilan data dilaksanakan pada bulan Juni 2009 di Desa Limbangan yang merupakan salah satu dari 13 desa di Kecamatan Kersana dengan tingkat pemakaian pestisida paling tinggi. Komoditas pertanian yang utama di desa tersebut adalah bawang merah dan cabe. Hasil wawancara dengan beberapa petani menunjukkan intensitas penyemprotan pestisida untuk bawang merah dan cabe sangat tinggi, mencapai 2-3 hari sekali, bahkan se-
Tabel 1. Karakterisitik WUS di Daeah Penelitian 2009

\begin{tabular}{llll}
\hline Karakteristik Subjek & Kategori & $\mathbf{n}$ & $\mathbf{( \% )}$ \\
\hline Status pernikahan & Menikah & 25 & 96,1 \\
& Janda & 1 & 3,9 \\
Terlibat pertanian & Ya & 22 & 84,6 \\
& Tidak & 4 & 15,4 \\
\hline Total & & 26 & 100,0 \\
\hline
\end{tabular}

Tabel 2. Distribusi Kegiatan Pertanian WUS di Daerah Penelitian 2009

\begin{tabular}{lll}
\hline Jenis kegiatan & n & $\%$ \\
\hline Membantu menyiapkan pestisida & 2 & 9,0 \\
Membantu menyemprot & 1 & 4,5 \\
Nguleri' & 19 & 86,4 \\
Memanen & 15 & 68,2 \\
'Mbrodoli' & 16 & 72,7 \\
Mencuci peralatan semprot/baju suami & 15 & 68,2 \\
\hline
\end{tabular}

tiap hari pada musim penghujan.

\section{Karakteristik Subjek}

Jumlah WUS yang disertakan dalam penelitian adalah 26 orang, dengan rerata umur $28,4( \pm 4,66)$ tahun, usia termuda 17 tahun dan yang tertua 37 tahun. Sebagian besar WUS $(84,6 \%)$ terlibat dalam kegiatan pertanian terutama sebagai buruh tani. Karakteristik subjek secara lengkap disajikan dalam Tabel 1.

Jenis kegiatan pertanian yang dilakukan WUS, sebagian besar adalah mencari hama ulat ('nguleri'), memetik saat panen, dan melepaskan bawang atau lombok dari tangkainya ('mbrodoli'). Sementara, yang melakukan penyemprotan pestisida hanya satu orang $(4,5 \%)$ (Lihat Tabel 2).

\section{Hasil Pemeriksaan Fisik dan Laboratorium}

Pemeriksaan fisik dan laboratorium yang dilakukan pada penelitian ini meliputi pemeriksaan palpasi kelenjar tiroid, pemeriksaan kadar TSH, fT4, T3, Cholinesterase, UEI dan kadar Pb dalam darah. Namun, pemeriksaan beberapa parameter laboratorium hanya dilakukan pada kelompok sub-sampel, yaitu T3 $(n=13)$, UEI $(n=6)$, dan $\mathrm{Pb}$ darah $(\mathrm{n}=5)$ (Lihat Tabel 3).

Dengan menggunakan batasan nilai TSH $>4,5$ $\mathrm{mIU} / \mathrm{mL}$ untuk hipotiroidisme ${ }^{15}$, maka didapatkan 12 WUS $(46,2 \%)$ menderita hipotirodisme. Bila melihat nilai fT4 dan T3, dimana untuk kedua parameter tersebut nilainya masih dalam batas normal, yakni 7,00 - 18,00 pmol/L untuk TSH dan 1,00 - 2,00 nmol/L untuk T3,15 maka hipotiroidisme yang didapatkan masih dalam kategori ringan (hipotiroidisme sub-klinis). Sementara, dari data kadar Cholinesterase, tidak didapatkan subjek yang 
Tabel 3. Nilai-nilai Deskriptif Hasil Pemeriksaan Laboratorium

\begin{tabular}{llll}
\hline Variabel/ Parameter & $\mathbf{n}$ & Rerata $( \pm \mathbf{S B})$ & Kisaran \\
\hline TSH $(\mathrm{mIU} / \mathrm{mL})$ & 26 & $5,09(6,14)$ & $0,47-31,73$ \\
$\mathrm{fT} 4(\mathrm{pmol} / \mathrm{L})$ & 26 & $15,18(2,09)$ & $8,73-18,87$ \\
$\mathrm{~T} 3(\mathrm{nmol} / \mathrm{L})$ & 13 & $1,75(0,51)$ & $1,24-2,95$ \\
Cholinesterase $(\mathrm{mkat} / \mathrm{L})$ & 26 & $7,26(1,28)$ & $5,33-9,39$ \\
UEI $(\mu \mathrm{g} / \mathrm{dL})$ & 6 & $290,00(10,81)$ & $268,00-295,00$ \\
$\mathrm{~Pb}(\mathrm{mg} / \mathrm{L})$ & 5 & $0,46(0,12)$ & $0,31-0,64$ \\
\hline
\end{tabular}

Tabel 4. Pembesaran Kelenjar Tiroid dan Hipotiroidisme WUS di Daerah Penelitian 2009

\begin{tabular}{llll}
\hline Variabel & Kategori & n & $\%$ \\
\hline Pembesaran kelenjar tiroid & Grade 0 & 14 & $(53,8)$ \\
& Grade 1 & 11 & $(42,3)$ \\
& Grade 2 & 1 & $(3,9)$ \\
Kejadian hipotiroidisme & Ya & 12 & $(46,2)$ \\
& Tidak & 15 & $(53,8)$ \\
\hline
\end{tabular}

Tabel 5. Hubungan Kegiatan Pertanian dan Hipotiroidisme WUS di Daerah Penelitian

\begin{tabular}{lccc}
\hline Kegiatan pertanian & Hipotiroidisme & $p$ & PR (95\% CI) \\
\hline Ya $(\mathrm{n}=22)$ & $\begin{array}{l}11(50,0 \%) \\
1(25,0 \%)\end{array}$ & 0,706 & $2,0(0,35-11,50)$ \\
Tidak $(\mathrm{n}=4)$ & & & \\
\hline
\end{tabular}

kadarnya $<3,9 \mu \mathrm{g} / \mathrm{L}$ (Lihat Tabel 4).

\section{Hubungan Kegiatan Pertanian dengan Hipotiroidisme}

Untuk memperoleh gambaran tentang hubungan pajanan pestisida dengan kejadian hipotiroidisme, dilakukan uji Chi-square. Hasil uji tersebut menunjukkan, tidak ada hubungan bermakna antara keterlibatan WUS dalam kegiatan pertanian dengan kejadian hipotiroidisme (nilai- $p=0,706 ; \mathrm{PR}=2,0 ; 95 \% \mathrm{CI}=0,35-11,50$ ). Namun, terdapat kecenderungan prevalensi hipotiroidisme lebih banyak pada kelompok WUS yang terlibat dalam kegiatan pertanian $(50,0 \%)$ dibanding pada kelompok yang tidak terlibat dalam kegiatan pertanian $(25,0 \%)$. Hasil uji Chi-square disajikan dalam Tabel 5.

\section{Pembahasan}

Hasil penelitian menunjukkan, kadar Cholinesterase pada subjek penelitian, semuanya masih dalam batas normal $(\geq 3,9 \mu \mathrm{g} / \mathrm{L})$, yang berarti belum terjadi kasus keracunan pestisida pada kelompok subjek. Hal ini kemungkinan karena tingkat pajanan yang dialami oleh WUS tidak terlalu berat. Hasil wawancara menunjukkan hanya ada satu WUS yang menyatakan ikut terlibat dalam kegiatan menyemprot. Sementara kegiatan lain yang melibatkan WUS adalah mencari hama (nguleri), mencabuti rumput, memanen, melepaskan bawang dari tangkainya (mbrodoli), dan membersihkan baju atau perlengkapan yang dipakai suami menyemprot. Berbagai kegiatan tersebut, meskipun berisiko pajanan pestisida, tetapi kemungkinan belum sampai pada tahap menghambat fungsi enzim Cholinesterase.

Sebaliknya, untuk parameter fungsi tiroid, hasil pemeriksaan laboratorium menunjukkan gangguan yang cukup signifikan, khususnya kadar TSH. Dilihat dari kadar fT4 dan T3 yang masih dalam batas normal, hipotiroidisme yang terjadi tergolong 'ringan' (hipotiroidisme sub-klinik). Prevalensi hipotiroidisme sub-klinik pada WUS yang mencapai $46,2 \%$ terbilang cukup tinggi. Penelitian di tempat lain menunjukkan angka yang lebih rendah. Prevalensi hipotiroidisme subklinik di seluruh dunia berkisar antara 1-10\%, prevalensi tertinggi pada wanita usia lebih dari 60 tahun. ${ }^{17}$ Penelitian Akhter, ${ }^{18}$ di Bangladesh mendapatkan prevalensi hipotiroidisme sub-klinik sebesar $6,5 \%$ pada wanita dengan infertilitas primer dan $15,0 \%$ pada wanita dengan infertilitas sekunder. Penelitian Sukati, ${ }^{19} 2006$ di Kabupaten Magelang mendapatkan WUS dengan kadar fT4 $<0,79 \mathrm{ng} / \mathrm{L}$ mencapai $29,8 \%$, tetapi penelitian dilakukan di daerah endemis gondok, dengan temuan asupan yodium kurang mencapai 50,6\%. Di daerah endemis, hipotiroidisme merupakan penyebab utama kasus gondok yang terjadi akibat asupan yodium yang kurang. Namun, di lokasi penelitian, asupan yodium cukup memadai (nilai median pada sub-sampel $>150 \mu \mathrm{g} / \mathrm{d}$ ). Sehubungan dengan itu, beberapa faktor yang perlu dicurigai sebagai penyebabnya, salah satu adalah kemungkinan pajanan pestisida.

Beberapa teori menerangkan, bahwa pajanan pestisi$\mathrm{da}$, dari golongan organoklorin dan organosfosfat dapat menekan sintesis hormon tiroid. Pestisida dapat mengganggu proses sintesis hormon tiroid melalui beberapa mekanisme meliputi: (1) Mengganggu reseptor TSH (TSH-r) di kelenjar tiroid sehingga TSH yang akan memacu sintesis hormon tiroid tidak dapat masuk ke dalam kelenjar yang berdampak pada hambatan sintesis hormon tiroid. (2) Pestisida menghambat kerja enzim deiodinase tipe 1 (D1) yang berfungsi mengkatalis perubahan T4 menjadi T3 (bentuk aktif hormon dalam tubuh). (3) Kemiripan struktur kimia antara pestisida 
dan hormon tiroid menyebabkan persaingan dalam pengikatan oleh reseptor hormon tiroid (TH-r) di sel target. (4) Pestisida diduga memacu kerja enzim D3 yang berfungsi merubah T4 menjadi rT3 (bentuk inaktif hormon tiroid), sehingga tubuh merasakan kekurangan bentuk aktif hormon tiroid (T3). ${ }^{1}$ Penelitian pada binatang membuktikan penurunan kadar T4 dan T3 serta peningkatan kadar TSH pada tikus yang diberi pajanan pestisida golongan organofosfat. ${ }^{20,21}$ Penelitian Toft, ${ }^{22}$ di Denmark menunjukkan peningkatan kadar TSH petani sebesar $32 \%$ pada musim tanam.

Hasil uji Chi-square belum menunjukkan adanya hubungan (bermakna) antara keterlibatan WUS dalam kegiatan pertanian dengan kejadian hipotiroidisme. Namun, adanya kecenderungan kejadian hipotirodisme lebih banyak pada kelompok WUS yang terlibat dalam kegiatan pertanian dibanding pada kelompok yang tidak terlibat, membuat kita harus berfikir untuk membuktikan hipotesis tersebut. Jumlah subjek yang 'terbatas' merupakan salah satu penyebab belum terbuktinya hubungan tersebut. Selain itu, metode pengukuran pajanan pestisida perlu ditingkatkan validitasnya. Kadar Cholinesterase yang masih dalam batas normal pada semua subjek, menimbulkan suatu kemungkinan baru, yaitu pajanan pestisida yang ringan, ternyata sudah memberikan dampak negatif terhadap fungsi tiroid.

Selain pajanan pestisida, masih ada beberapa faktor risiko lain yang layak diperhitungkan sebagai penyebab atau mungkin berkontribusi terhadap kejadian hipotiroidisme tersebut meliputi pajanan logam berat seperti Plumbum $(\mathrm{Pb})$ dan kadmium $(\mathrm{Cd})$ serta pajanan polychlorinated biphneyl (PCB). Pb merupakan logam berat yang dapat masuk ke dalam tubuh melalui makanan (terutama produk-produk laut) atau melalui pernafasan (pencemaran udara). Sementara PCB, merupakan bahan utama dalam pembuatan plastik yang banyak dipakai oleh masyarakat sebagai wadah/pembungkus makanan. Kedua polutan tersebut ( $\mathrm{Pb}$ dan $\mathrm{PCB}$ ) dapat menghambat sintesis hormon trioid. $\mathrm{Pb}$ dapat menghambat penangkapan yodium oleh kelenjar tiroid, melalui kompetisi ikatan dengan Natrium Iodide Symporter (NIS), sehingga kelenjar tiroid akan kekurangan yodium, yang merupakan bahan baku utama sintesis hormon tiroid. Sementara PCB, sama dengan pestisida, menghambat sintesis hormon tiroid melalui mekanisme hambatan terhadap TSH-r, D1, dan TH-r serta memacu kerja enzim D3.

Meskipun hampir semua kasus yang ditemukan adalah hipotiroidisme ringan (sub-klinis), tetapi hal tersebut harus tetap diperhatikan karena hipotiroidisme sub-klinis berefek cukup signifikan terhadap kesehatan reproduksi WUS seperti infertilitas, abortus spontan, placental abruption, kelahiran pre-term, berat bayi lahir rendah (BBLR), bahkan gangguan tumbuh-kembang pada anak yang dilahirkan oleh ibu dengan hipotiroidisme sub-klinis di awal kehamilannya. 18,23,24

Berkaitan dengan uraian di atas, diperlukan kajian lebih lanjut untuk membuktikan bahwa pajanan pestisida merupakan faktor risiko gangguan fungsi tiroid, khususnya hipotiroidisme, pada WUS yang bertempattinggal di darah pertanian. Beberapa hal yang harus diperhatikan untuk penelitian selanjutnya adalah meningkatkan jumlah subjek dan memperluas area penelitian, memeriksa variabel lain yang mungkin ikut bertanggungjawab terhadap kejadian hipotiroidisme, seperti kadar $\mathrm{Pb}$ darah, kadar tiosianat urin, riwayat pajanan PCB, dan lain-lain.

\section{Kesimpulan}

Pada penelitian ini tidak didapatkan kasus keracunan pestisida pada WUS yang bermukim di lokasi penelitian. Prevalensi kejadian hipotiroidisme pada WUS adalah $46,2 \%$ tidak ada hubungan bermakna antara keterlibatan WUS dalam kegiatan pertanian dengan kejadian hipotiroidisme. Namun, terlihat kecenderungan prevalensi hipotiroidisme relatif lebih besar pada kelompok WUS yang terlibat dalam kegiatan pertanian daripada kelompok WUS yang tidak terlibat.

\section{Saran}

Berdasarkan hasil penelitian ini, beberapa hal yang disarankan adalah (1) perlu dikembangkan penelitian lebih lanjut dengan pengukuran variabel yang lebih akurat, terutama untuk mengukur dosis pajanan (mengukur kadar pestisida atau metabolitnya dalam darah/urin) dan mengukur parameter fungsi tiroid yang lain, seperti kadar T3 dan rT3 agar dapat dijelaskan secara lebih jelas tentang patofisiologi terjadinya hipotiroidisme akibat pajanan pestisida. Selain itu, pengukuran terhadap bahan toksik di lingkungan yang lain, seperti $\mathrm{Pb}, \mathrm{Cd}$ dan $\mathrm{PCB}$ juga diperlukan, agar pengendalian terhadap faktor perancu dapat lebih optimal. (2) Bagi instansi terkait, terutama Dinas Kesehatan, agar mengembangkan program monitoring fungsi tiroid dan memberikan perhatian serius terhadap kesehatan reproduksi WUS yang bertempat tinggal di daerah pertanian, mengingat jumlah mereka yang sangat besar.

\section{Ucapan Terima Kasih}

Terima kasih kepada: Dekan Fakultas Kesehatan Masyarakat Universitas Diponegoro (FKM UNDIP) yang telah mengijinkan penulis untuk menggunakan dana penelitian DIPA FKM UNDIP tahun anggaran 2009; Ketua Unit Pengembangan Penelitian (UPP) FKM UNDIP; seluruh subjek penelitian di empat desa kecamatan Kersana, kabupaten Brebes; dan seluruh tim peneliti. 


\section{Daftar Pustaka}

1. Boas M, Rasmussen UF, Skakkebaek NE, Main KM. Environmental chemicals and thyroid function. European Journal of Endocrinology. 2006; 154: 599-611.

2. Takser L, Mergler D, Baldwin M, Grosbois Sd, Smargiassi A, Lafond J. Thyroid hormones in pregnancy in relation to environmental exposure to organochlorine compounds and mercury. Environmental Health Perspectives. 2005; 113 (8): 1039-45.

3. Guven M, Bayram F, Unluhizarci K, Kelestimur F. Endocrine changes in patients with acute organophosphate poisoning. Human \& Experimental Toxicology. 1999; 18: 598-601.

4. Djokomoeljanto R. Penyakit kelenjar gondok (sebuah tinjauan populer). Semarang: CV Agung; 2007. p.1-98.

5. Wiersinga WM. Adult hypothyroidism [edisi 2004, diakses tanggal 281-2008]. Diunduh dari: www.thyroidmanager.org/ Chapter9/9. frame.htm.

6. Djokomoeljanto R_3. Gangguan akibat kurang iodium (GAKI) dan kelebihan yodium (ekses). Buku Ajar Tiroidologi Klinik. Editor: Djokomoeljanto. Cetakan 1. Semarang: Badan Penerbit Universitas Diponegor; 2007. hal. 377-423.

7. Dunn JT. Iodine should be routinely added to complementary foods. The Journal of Nutrition. 2003; 133: 3008S-10S.

8. Hetzel BS. Iodine and Neuropsychological development. The Journal of Nutrition. 2000; 130: 493S-5S.

9. Pop VJ, Brouwers EP, Vader HL, Vulsma T, van Baar AL, de Vijlder JJ. Maternal hypothyroxinaemia during early pregnancy and subsequent child development: a 3-year follow-up study. Clinical Endocrinology. 2003; 59 (3): 282-8.

10. Djokomoeljanto R_1. Sekilas sejarah kelenjar tiroid. Buku Ajar Tiroidologi Klinik. Editor: Djokomoeljanto. Semarang: Badan Penerbit Universitas Diponegor; 2007. Hal. 1-10.

11. Adriani M, Wirjatmadi B, Gunanti IR. Identifikasi gondok di daerah pantai: suatu gangguan akibat kekurangan yodium. Jurnal Gaky Indonesia (Indonesian Journal of IDD). 2002: 3 (1): 17-30.

12. Wade MG, Parent S, Finnson KW, Foster W, Younglai E, Mcmahon A, et al. Thyroid toxicity due to subchronic exposure to a complex mixture of 16 organochlorines lead, cadmium. Toxicological Sciences. 2002; 67: 207-18.
13. Henson MC, Chedrese PJ. Endocrine disruption by cadmium, a common environmental toxicant with paradoxical effects on reproduction. Society for Experimental Biology and Medicine. 2004: 383-92.

14. WHO. Assessment of iodine deficiency disorders and monitoring their elimination. A Guide for Programme Manager. Second Edition. WHO: 2007.

15. Stone MB, Walace RB. Medicare coverage of routine screening for thyroid dysfunction. National Academy of Sciences. Diunduh dari: http://www.nap.edu/catalog/10682.html.

16. Wijaya A, Kaniawati M. Evaluasi laboratorik faal tiroid orang normal dan dalam keadaan sakit. Buku Ajar Tiroidologi Klinik. Editor: Djokomoeljanto. Cetakan 1. Semarang: Badan Penerbit Universitas Diponegoro; 2007. Hal. 67-99, .

17. Cooper DS. Sub-clinical hypothyroidism. N Engl J Med. 2001; 354 (4): 260-5.

18. Akhter N, Hassan SA. Sub-clinical hypothyroidism and hyperprolactinemia in infertile women: Bangladesh perspective after universal salt iodination. The Internet Journal of Endocrinology. 2009; 5 (1).

19. Sukati S, Suryati K, Ichsan M, Mucherdiyantiningsih, Kartono D. Hubungan kadar enzyme kholinesterase dengan kadar hormone thyroid pada WUS di daerah gondok endemic. Puslitbang Gizi dan Makanan. 2006; 29 (1): 38-47.

20. Akhter N, Kayani SA, Ahmad M, Shahab M. Insecticide-induced changes in secretory activity of the thyroid gland in rats. Journal of Applied Toxicology. 1998; 16 (5): 397-400.

21. Jeong S, Kim B, Kang H, Ku H, Cho J. Effect of chlorpyrifos-methyl on steroid and thyroid hormones in rat F0- and F1- generations. Toxicology Division. National Veterinary Research and Quarantine Service. Elsevier Ireland Ltd; 2006.

22. Toft G, Flyvjerg A, and Bonde JP. Thyroid function in Danish greenhouse workers. Environmental Health: A Global Access Science Source. 2006; 5:32

23. Casey BM, Dashe JS, Wells CE, McIntire DD, Byrd W, Leveno KJ, et al. Sub-clinical hypothyroidism ang pregnancy outcomes. Obstet Gynecol. 2009; 105 (2): 239-45.

24. Screening women for thyroid disorder during pregnancy: sub-clinical hypothyroidism and adverse pregnancy outcomes [di akses tanggal 1810-1009]. Diunduh dari: http://www.medscape.com/532173-7. 